\title{
INJURIES AS EXPOSURE EVENTS IN PROVIDING MEDICAL SERVICES BY NURSING STAFF
}

\section{ZDARZENIA EKSPOZYCYJNE W CZASIE UDZIELANIA ŚWIADCZEŃ MEDYCZNYCH PRZEZ PERSONEL PIELĘGNIARSKI}

\author{
${ }^{1}$ Andrzej Frycz Modrzewski Krakow University, Faculty of Medicine and Health Sciences \\ ${ }^{2}$ Jagiellonian University Medical College, Kraków Institute of Mycology, Department of Microbiology \\ ${ }^{1}$ Krakowska Akademia im. Andrzeja Frycza Modrzewskiego Wydział Lekarski i Nauk o Zdrowiu, Kraków \\ ${ }^{2}$ Uniwersytet Jagielloński Collegium Medicum Zakład Mykologii, Katedra Mikrobiologii, Kraków
}

\begin{abstract}
INTRODUCTION. Among medical staff, nurses are particularly vulnerable to occupational exposure since they provide direct patient care and perform medical activities which often involve using sharps.

AIM. The objective of the study was to examine the frequency of injuries and their causes in nursing.

METHODS. A diagnostic survey was employed using an original questionnaire. The study was carried out from 3rd March to 2nd April 2017. The study group comprised part-time nursing students. 107 respondents participating in the study worked in out-patient (28\%) and in-patient (72\%) healthcare. Most of the respondents were aged $41-50(34.6 \%)$.

RESULTS. $61.7 \%$ of the respondents were injured at work. The injury reporting rate was: $19.7 \%$ always, $22.7 \%$ often, $30.3 \%$ rarely, and $27.3 \%$ never. The most commonly mentioned types of injuries included: prick (51.5\%), cut $(28.8 \%)$, scratch $(10.6 \%)$, prick and cut $(9.1 \%)$. The incidence of injuries varied. $48.5 \%$ of the studied people declared fewer than 5 incidents, $31.8 \%$ quoted 5-10 injuries, $6.1 \%$ recalled $11-20,13.6 \%$ did not remember such a situation. For nurses with longer seniority, there is a significant increase in injuries $(p=0.029)$. Sources of injuries were most often: injection needle (35.9\%), ampoule with medicine $(23.3 \%)$, pen $(7.8 \%)$.

CONCLUSIONS. Not all occupational exposure cases are reported by nurses. Seniority determines injury incidence among nurses. The longer the seniority, the more common the injuries. The needle causes injuries most frequently.
\end{abstract}

Key words: exposure events, nursing staff, injuries

\section{STRESZCZENIE}

WSTĘP. Na ekspozycję zawodową wśród personelu medycznego szczególnie narażone są pielęgniarki sprawując bezpośrednią opiekę nad pacjentem i wykonując wiele czynności medycznych, które często wymagają zastosowania ostrych narzędzi.

CEL PRACY. Celem pracy było zbadanie częstości zranień oraz ich przyczyn w pracy pielęgniarki.

METODY. Zastosowano metodę sondażu diagnostycznego, technikę ankiety z autorskim kwestionariuszem. Badanie przeprowadzono w okresie od 03 marca do 02 kwietnia 2017 roku. Grupę badaną stanowili studenci studiów niestacjonarnych na kierunku pielęgniarstwo. W badaniu wzięło udział 107 respondentów pracujących w placówkach lecznictwa otwartego (28\%) jak i zamkniętego (72\%). Najwięcej ankietowanych było w wieku 41-50 lat (34,6\%). Zranieniu podczas pracy uległo $61,7 \%$ ankietowanych.

WYNIKI. Zawsze zgłaszało zranienie $19,7 \%$ badanych, często $22,7 \%$, rzadko $30,3 \%$, nigdy nie zgłaszało $27,3 \%$ badanych. Do najczęściej wymienianych rodzajów zranień należały: zakłucie igłą $(51,5 \%)$, skaleczenie $(28,8 \%)$, zadrapanie $(10,6 \%)$, zakłucie i skaleczenie $(9,1 \%)$. Częstość występowania zranień była zróżnicowana. Poniżej pięciu incydentów deklarowało 48,5\% badanych, 5-10 zranień podało 31,8\%, 11-20 zranień wystąpiło u 6,1\%,

(C) National Institute of Public Health - National Institute of Hygiene / Narodowy Instytut Zdrowia Publicznego - Państwowy Zakład Higieny 
nie pamiętało takiej sytuacji 13,6\% respondentów. Wraz ze stażem pracy pielęgniarek istotnie wzrasta liczba zranień $(\mathrm{p}=0,029)$. Źródło zranień najczęściej stanowiły: igła iniekcyjna $(35,9 \%)$, ampułka z lekiem $(23,3 \%)$, pen $(7,8 \%)$.

WNIOSKI. Nie każdy przypadek ekspozycji zawodowej jest zgłaszany przez pielęgniarki. Staż pracy determinuje częstość występowania zranień pielęgniarek. Im dłuższy staż pracy tym częściej występują zranienia w pracy zawodowej. Najczęstszym sprzętem powodującym zranienia jest igła.

Słowa kluczowe: zdarzenia ekspozycyjne, personel pielegniarski, zranienia

\section{INTRODUCTION}

Invariably, occupational exposure continues to be a global problem for medical staff. Injuries, which may result from pricking the skin with a needle, cutting with a lancet or when opening drug ampoules, have both health as well as financial consequences $(1,2)$. Injuries are mainly associated with invasive procedures and injections in patients. The World Health Organization (WHO) estimated that in 2004 at least 3 million out of 37 million healthcare workers experienced at least one needlestick incident (3).

Nurses are particularly exposed to such incidents as they are the ones who provide direct patient care by performing a whole range of medical activities, which often require the application of various types of medical equipment $(4,5)$. A nurse's work environment, owing to its specificity, is equipped with all kinds of medical equipment, which often has sharp edges conducive to injuries. However, it is impossible to completely eliminate medical sharps from most medical procedures. The occurrence of cuts can be affected by work experience, experience, atmosphere in the workplace, haste, nervousness, stress, lack of cooperation on the part of patients and many other factors $(6,7)$.

\section{OBJECTIVE OF THE STUDY}

The objective of the study is to investigate the frequency of injuries and their causes in the nurse's work.

\section{MATERIAL AND METHODS}

In the present study, the diagnostic survey method was employed and an original questionnaire was our research tool. The questionnaire made use of both open-ended and closed-ended questions. The survey was carried out from 3rd March to 2nd April, 2017, at Andrzej Frycz Modrzewski Kraków University.

Statistical calculations in this study were made using STATISTICA v12, StatSoft, Inc (2012). The assumed level of statistical significance for the test was $\mathrm{p}<0.05$. In order to investigate differences in parameter

\section{WSTĘP}

Ekspozycja zawodowa niezmiennie pozostaje problemem ogólnoświatowym wśród personelu medycznego. Zranienia, które mogą powstać na skutek zakłucia igłą, skaleczenia lancetem, czy otwierania ampułki z lekiem niosą ze sobą konsekwencje przede wszystkim zdrowotne, a także finansowe $(1,2)$. Zranienia związane są głównie z procedurami inwazyjnymi oraz wykonywaniem iniekcji u pacjentów. Światowa Organizacja Zdrowia (ang. World Health Organization, WHO) oszacowała, iż w 2004 roku co najmniej 3 miliony z 37 milionów pracowników służby zdrowia doświadczyło co najmniej jednego incydentu zakłucia igłą (3).

Szczególnie narażone na takie incydenty są pielęgniarki, gdyż to właśnie one sprawują bezpośrednią opiekę nad pacjentem wykonując cały szereg czynności medycznych, które wymagają często zastosowania różnego rodzaju sprzętu medycznego $(4,5)$. Stanowisko pracy pielęgniarki ze względu na swoją specyfikę wyposażone jest we wszelkiego rodzaju sprzęt medyczny, który często posiada ostre zakończenia, sprzyjające powstawaniu zranień. Jednak nie jest możliwe całkowite wyeliminowanie ostrych narzędzi medycznych z większości procedur medycznych. Na wystąpienie skaleczeń mogą mieć wpływ staż pracy, doświadczenie, atmosfera panująca w miejscu pracy, pośpiech, zdenerwowanie, stres, brak współpracy ze strony pacjentów i wiele innych czynników $(6,7)$.

\section{CEL PRACY}

Celem pracy było zbadanie częstości zranień oraz ich przyczyn $\mathrm{w}$ pracy pielęgniarki.

\section{MATERIAŁ I METODY}

W niniejszym badaniu wykorzystano metodę sondażu diagnostycznego oraz technikę ankiety, a narzędziem badawczym był autorski kwestionariusz ankiety. W kwestionariuszu zastosowane zostały dwa rodzaje pytań: otwarte oraz zamknięte. Sondaż przeprowadzono w okresie od 3 marca do 2 kwietnia 2017 roku na terenie Krakowskiej Akademii im. Andrzeja Frycza Modrzewskiego w Krakowie. 
distributions on the ordinal scale, a nonparametric Mann-Whitney U test was applied. At the same time, to examine the relationship, the nonparametric Spearman correlation coefficient was determined.

Characteristics of the test group. The test group comprised part-time postgraduate nursing students already holding a bachelor's degree in nursing. 107 respondents took part in the survey. Women constituted $98.1 \%$ and men made up the remaining $1.9 \%$. The largest groups of respondents included subjects aged $41-50$ years $(34.6 \%)$ and under 30 years $(29.0 \%)$. Smaller groups consisted of people aged $31-40$ years $(19.6 \%)$ and over 50 years $(16.8 \%)$. Among the subjects, $28 \%$ of workers were employed in out-patient healthcare and $72 \%$ of them in in-patient healthcare. In the latter group, most respondents were employed in the department of anesthesiology and the intensive care unit (ICU) $(15.0 \%)$, the cardiology unit $(13.1 \%)$ and the department of internal diseases $(10.3 \%)$. Smaller groups worked in the following departments: neurology (6.5\%), neuropsychiatry, orthopedics and trauma (5.6\%), operating room (4.7\%), urological, vascular $(3.7 \%)$ oncology $(2.8 \%)$, pulmonology (2.8\%), infectious diseases, pediatrics, emergency $(1.9 \%)$, ENT, neonatology, psychiatry and rheumatology $(0.9 \%)$. The majority of the respondents had a work experience of less than 5 years $(25.2 \%)$. The second group were respondents declaring a work experience of 21-30 years (23.3\%), followed by a work experience of 11-20 years (21.5\%). Furthermore, 32 people confirmed that they had a work experience of $5-10$ years $(15.0 \%)$ and of over 30 years $(15.0 \%)$.

\section{RESULTS}

Over half of the respondents (61.7\%) declared that they suffered from an injury in the course of their professional work, while the rest of the subjects $(38.3 \%)$ denied that such an incident ever occurred. According to those polled, the most frequent type of injuries, which they experienced while performing their professional duties, were needlestick injuries $(51.5 \%)$, followed by cuts $(28.8 \%)$, scratches $(10.6 \%)$, as well as simultaneous needlestick injury and cut $(9.1 \%)$.

The incidence of injuries in the group studied varied. Fewer than five incidents of injury were declared by $48.5 \%$ of the subjects; $31.8 \%$ of the studied people gave a number of 5-10; while $6.1 \%$ of them experienced from 11 to 20 injuries. $13.6 \%$ of the respondents did not recall such a situation. With the rise in respondents' work experience, there was a significant increase in the number of injuries $(\mathrm{p}=0.029453)$. As a result of the statistical analysis conducted, a significant positive correlation has been found between the work experience and the number of injuries
Obliczenia statystyczne w tym badaniu wykonano za pomocą programu STATISTICA v12, StatSoft, Inc (2012). Przyjęto poziom istotności testu $\mathrm{p}<0,05$. W celu zbadania różnic w rozkładach parametrów na skali porządkowej zastosowano test nieparametryczny Manna-Whitneya. Natomiast dla zbadania zależności wyznaczono współczynnik korelacji nieparametrycznej Spearmana.

Charakterystyka grupy badanej. Grupę badaną stanowili studenci studiów niestacjonarnych II stopnia na kierunku pielęgniarstwo, posiadający tytuł zawodowy licencjat pielęgniarstwa. W badaniu wzięło udział 107 ankietowanych, w tym kobiety stanowiły 98,1\%, a mężczyźni 1,9\%. Najliczniejsza grupa badanych osób była w przedziale wiekowym 41-50 lat $(34,6 \%)$ i poniżej 30 roku życia $(29,0 \%)$. Mniejszą grupę stanowily osoby w przedziale wiekowym $31-40$ lat $(19,6 \%)$ oraz powyżej 50 roku życia (16,8\%). Wśród badanych, $28 \%$ osób pracowało w placówkach lecznictwa otwartego, a $72 \%$ w placówkach lecznictwa zamkniętego. W drugiej grupie najwięcej respondentów zatrudnionych było w oddziale anestezjologii i intensywnej terapii (OIOM) $(15,0 \%)$, kardiologii $(13,1 \%)$ oraz oddziale chorób wewnętrznych $(10,3 \%)$. Mniej liczne grupy pracowały na oddziałach: neurologii $(6,5 \%)$, neuropsychiatrii, urazowo-ortopedycznym $(5,6 \%)$, bloku operacyjnym $(4,7 \%)$, urologicznym, chorób naczyń $(3,7 \%)$ onkologii $(2,8 \%)$, pulmonologii $(2,8 \%)$, chorób zakaźnych, pediatrii, ratunkowym $(1,9 \%)$, laryngologii, neonatologii, psychiatrii i reumatologii $(0,9 \%)$. Najwięcej respondentów posiadało staż pracy krótszy niż 5 lat $(25,2 \%)$. Drugą grupę stanowili respondenci deklarujący staż pracy w przedziale 21-30 lat $(23,3 \%)$, następnie staż w przedziale $11-20$ lat $(21,5 \%)$. Ponadto 32 osoby potwierdzily, że staż ich pracy wynosi 5-10 lat (15,0\%) oraz powyżej 30 lat $(15,0 \%)$.

\section{WYNIKI}

Ponad połowa respondentów $(61,7 \%)$ zadeklarowała, iż uległa zranieniu w trakcie swojej pracy zawodowej, natomiast pozostała część badanych (38,3\%) zaprzeczyła, aby doszło do takiego incydentu. Według ankietowanych najczęstszym rodzajem zranienia, któremu ulegli podczas wykonywania swoich obowiązków zawodowych było zakłucie igłą (51,5\%), skaleczenie $(28,8 \%)$, zadrapanie $(10,6 \%)$, zakłucie i jednocześnie skaleczenie $(9,1 \%)$.

Częstość występowania zranień $\mathrm{w}$ badanej grupie była zróżnicowana. Poniżej pięciu incydentów zranień deklarowało $48,5 \%$ badanych, 5-10 podało $31,8 \%$ badanych, a od 11do 20 zranień wystąpiło u $6,1 \%$, nie pamiętało takiej sytuacji 13,6\% respondentów. Wraz ze stażem pracy respondentów istotnie wzrastała liczba zranień $(\mathrm{p}=0,029453)$. W wyniku przeprowadzonej analizy statystycznej stwierdzono istotną zależność dodatnią pomiędzy stażem pracy a liczbą zranień wśród respondentów. To znaczy, że wraz z długością stażu pracy wzrasta- 
among the respondents. That is to say that together with the length of employment, there was an increase in the number of injuries among the subjects. The sources of the injuries were most often: injection needles (35.9\%), drug ampoules (23.3\%), and insulin pens (7.8\%) (Fig. 1). ła liczba zranień wśród ankietowanych. Źródło zranień najczęściej stanowiły: igła iniekcyjna $(35,9 \%)$, ampułka $\mathrm{z}$ lekiem $(23,3 \%)$, pen do insuliny $(7,8 \%)$ (Ryc. 1$)$.

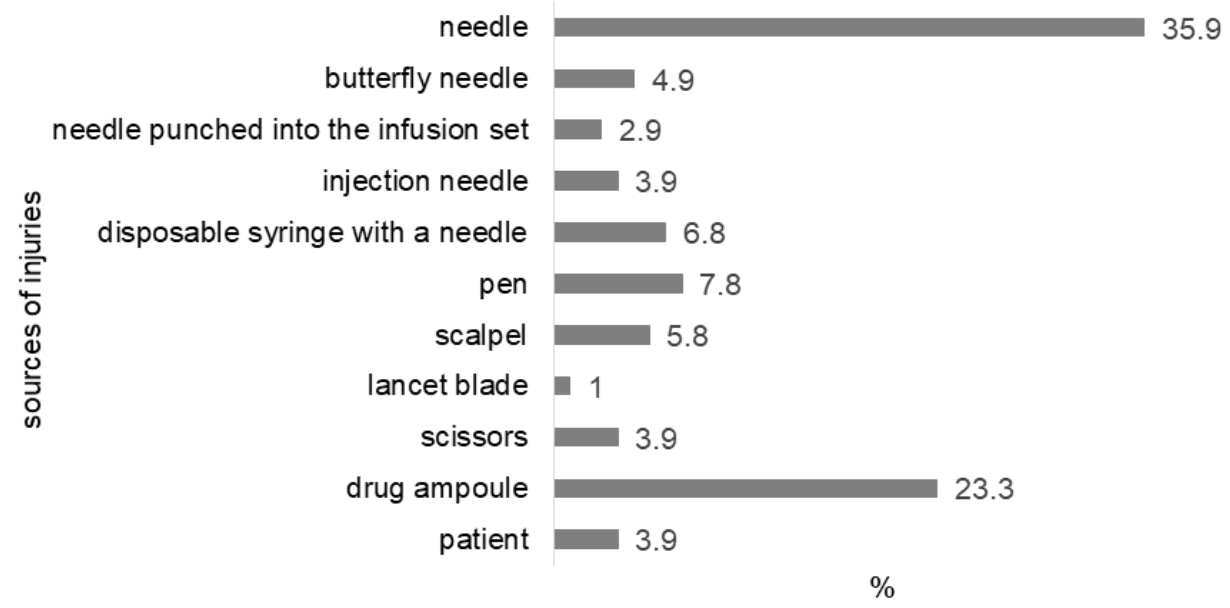

Fig. 1. The sources of exposure occurrences declared by respondents.

Ryc. 1. Źródła zranień deklarowane przez respondentów.

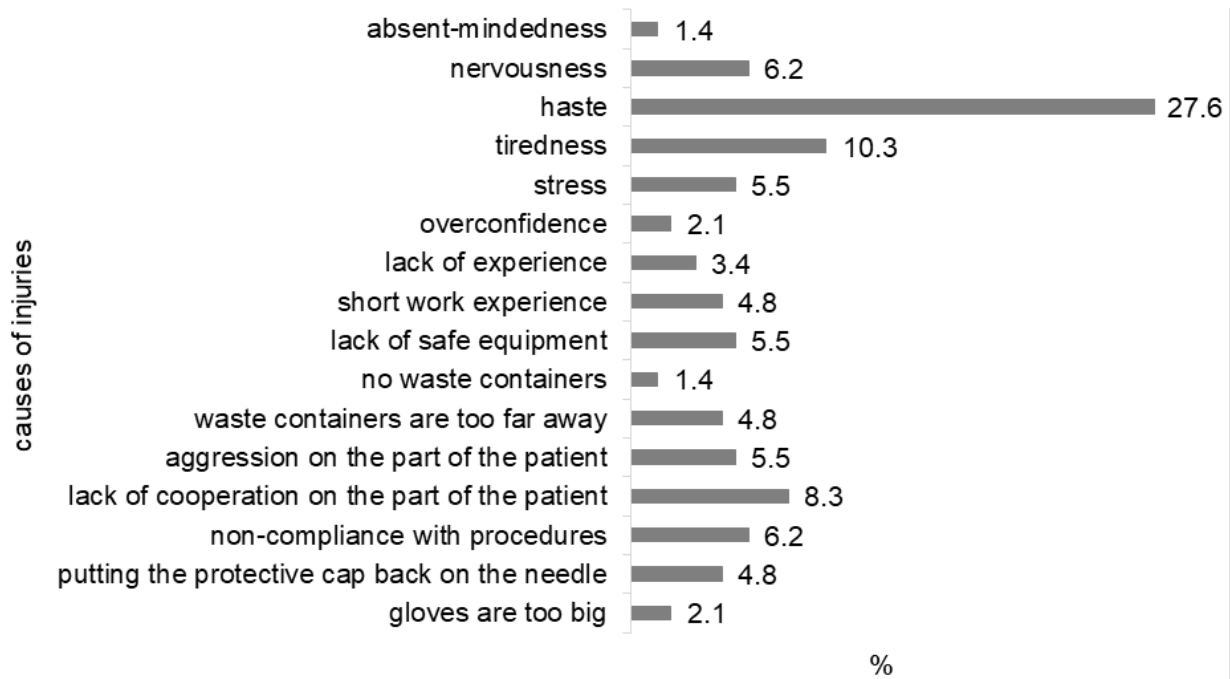

Fig. 2. Causes of injuries in the study group.

Ryc. 2. Przyczyny zranień w grupie badanej.

The causes of injuries, which were reported by the respondents most frequently, were: haste, fatigue, lack of cooperation on the part of the patient, non-compliance with procedures and the lack of safe equipment (Fig. 2). Among the subjects, $19.7 \%(\mathrm{n}=13)$ always report an injury, $22.7 \%$ $(\mathrm{n}=15)$ do it often, $33.3 \%(\mathrm{n}=20)$ do it rarely and as many as $27.3 \%(\mathrm{n}=18)$ never do it. According to $35.5 \%$ of the people surveyed, the experience gained during the working years has significant importance and influences the frequency of injuries among the nursing staff; however, $43.0 \%$ of the subjects claimed that work experience does not affect the frequency of injuries. $21.5 \%$ of the respondents had no opinion on this issue. The number of injuries suffered by the nursing staff depending on their work experience was presented in Table 1 .
Przyczyny zranień, najczęściej opisywane przez badanych to: pośpiech, zmęczenie, brak współpracy ze strony chorego, nieprzestrzeganie procedur oraz brak bezpiecznego sprzętu (Ryc. 2). Wśród ankietowanych $19,7 \%(n=13)$ zawsze zgłasza zranienie, często robi to $22,7 \%(\mathrm{n}=15)$, rzadko $33,3 \%(\mathrm{n}=20)$, a nigdy aż $27,3 \%$ $(n=18)$. W opinii $35,5 \%$ osób ankietowanych doświadczenie zdobyte $\mathrm{w}$ trakcie stażu pracy ma istotne znaczenie i wpływa na częstość zranień wśród personelu pielegniarskiego, jednak $43,0 \%$ badanych stwierdziło, iż staż pracy nie ma wpływu na częstość występowania zranień. Natomiast 21,5\% badanych nie miało zdania w tej kwestii. Liczbę zranien, jakiej ulegał personel pielęgniarski w zależności od stażu pracy przedstawiono w tabeli I. 
Table I. The number of injuries in nursing staff depending on work experience in the group.

Tab. I. Liczba zranień w grupie personelu pielęgniarskiego w zależności od stażu pracy.

\begin{tabular}{|c|c|c|c|c|c|c|c|c|c|}
\hline \multirow{3}{*}{$\begin{array}{c}\text { WORK } \\
\text { EXPERIENCE }\end{array}$} & \multicolumn{8}{|c|}{ NUMBER OF INJURIES } & \multirow{3}{*}{$\begin{array}{c}\text { Statistical significance } \\
\text { for } p<0.05(p=0.029453)\end{array}$} \\
\hline & \multicolumn{2}{|c|}{$<5$} & \multicolumn{2}{|c|}{$5-10$} & \multicolumn{2}{|c|}{$11-20$} & \multicolumn{2}{|c|}{ TOTAL } & \\
\hline & $\mathbf{n}$ & $\%$ & $\mathbf{n}$ & $\%$ & $\mathbf{n}$ & $\%$ & $\mathbf{n}$ & $\%$ & \\
\hline$<5$ years & 9 & 15.8 & 3 & 5.3 & 0 & 0 & 12 & 21.1 & \multirow{6}{*}{$\begin{array}{c}\text { Nonparametric Spearman } \\
\text { correlation coefficient } \\
\text { Rs }=+0.28867\end{array}$} \\
\hline $5-10$ years & 6 & 10.5 & 4 & 7 & 0 & 0 & 10 & 17.5 & \\
\hline $11-20$ years & 10 & 17.5 & 7 & 12.3 & 0 & 0 & 17 & 29.8 & \\
\hline 21-30 years & 4 & 7 & 3 & 5.3 & 1 & 1.8 & 8 & 14 & \\
\hline$>30$ years & 3 & 5.3 & 4 & 7 & 3 & 5.3 & 10 & 17.5 & \\
\hline TOTAL & 32 & 56.1 & 21 & 36.8 & 4 & 7.1 & $57 *$ & 100 & \\
\hline
\end{tabular}

*Out of 66 respondents who declared that they got injured during work, only 57 people provided an answer on their length of work experience.

The statistical analysis carried out allowed us to observe a significant increasing correlation between work experience and the number of injuries among nurses (nonparametric Spearman correlation coefficient $\mathrm{Rs}=+0.28867 ; \mathrm{p}=0.029453)$. That means that with the increase in work experience, there are more injuries among nurses.

The most numerous group of respondents declared that the cause of injuries is haste $(18.5 \%)$, followed by insufficient numbers of medical personnel (10.1\%), too many duties $(9.7 \%)$ and lack of safe equipment at the workplace $(8.4 \%)$. The fewest respondents indicated lack of skills, aggression on the part of the patient $(2.6 \%)$ or stress $(1.3 \%)$.

The majority of the subjects pointed out that increasing the number of nurses on call will prevent injuries among the nursing staff $(29.0 \%)$. Fewer people mentioned trainings $(15.5 \%)$ and supplying workplaces with safe equipment $(13.5 \%)$. The least frequently indicated aspects were reducing the amount of responsibilities of nurses $(1.5 \%)$, limiting the number of patients in the units $(1.5 \%)$ and increasing the amount of time spent on leisure $(1.0 \%)$.

The surveyed workers who had never reported an occurrence of a breach in the continuity of skin tissue in the course of their professional career stated that the most commonreason behind it was lack oftime (38.9\%), followed by no obligation to report such incidents (33.3\%), fear of having to undergo medical testing and waiting for results $(16.7 \%)$ and too many formalities when reporting such situations (11.1\%). The majority of the surveyed workers $(90.7 \%)$ declared that they had sufficient knowledge in the field of prevention of injuries, while $9.3 \%$ of them stated that they did not know whether they had such knowledge. Nobody said that they had no knowledge in this area. $39.3 \%$ of respondents gain the knowledge about injury prevention through their participation in trainings. $25.2 \%$ of people pinpointed the epidemiological nurse as their source of information, while $19.6 \%$ of the studied subjects declared self-education. The fewest people covered by the study explained that they gain information on injury prevention form the literature $(5.6 \%)$ and leaflets $(2.8 \%)$.
Przeprowadzona analiza statystyczna pozwoliła stwierdzić istotną zależność rosnącą pomiędzy stażem pracy a liczbą zranień wśród pielęgniarek (współczynnik korelacji nieparametrycznej Spearmana Rs $=+0,28867$; $\mathrm{p}=0,029453)$. Oznacza to, że wraz ze wzrostem stażu pracy wzrasta liczba zranień wśród pielęgniarek.

Większość ankietowanych wskazała, iż zwiększenie obsady personelu pielęgniarskiego na dyżurach zapobiegnie zranieniom wśród personelu pielęgniarskiego $(29,0 \%)$, w dalszej kolejności znalazły się szkolenia $(15,5 \%)$ i wyposażenie stanowisk pracy w bezpieczny sprzęt $(13,5 \%)$. Najmniej ankietowanych wskazało na zmniejszenie obowiązków pielęgniarskich $(1,5 \%)$, zmniejszenie liczby pacjentów na oddziałach $(1,5 \%)$ oraz zwiększenie czasu poświęconego na wypoczynek $(1,0 \%)$.

Ankietowani, którzy nigdy nie zgłaszali zaistniałych incydentów naruszenia ciągłości tkanki skórnej w trakcie pracy zawodowej stwierdzili, iż najczęstszym powodem był brak czasu (38,9\%), następnie brak obowiązku zgłaszania takich incydentów $(33,3 \%)$, obawa przed mającymi nastąpić badaniami i czasem oczekiwania na wyniki $(16,7 \%)$ oraz zbyt duża ilość formalności podczas zgłaszania takiej sytuacji $(11,1 \%)$. Większość ankietowanych $(90,7 \%)$ zadeklarowała, że posiada dostateczną wiedzę $\mathrm{w}$ zakresie profilaktyki zranień, natomiast 9,3\% uznało, że nie wie czy posiada taką wiedzę, żadna badana osoba nie podała, że nie posiada w tym zakresie żadnej wiedzy. Wiedzę z zakresu zapobiegania zranieniom 39,3\% ankietowanych na szkoleniach. Grupa licząca $25,2 \%$ jako źródło wiedzy wskazała pielęgniarkę epidemiologiczną, natomiast $19,6 \%$ badanych zadeklarowało samodzielną edukację. Najmniej osób objętych ankietą podało, że informacje o zapobieganiu zranieniom pozyskuje z literatury $(5,6 \%)$ oraz ulotek $(2,8 \%)$. Spośród ogółu badanych 79,4\% potwierdziło, iż na terenie ich zakładu pracy przeprowadzane są szkolenia z zakresu profilaktyki zranień. Pozostali podali, że w zakładach pracy, w których są zatrudnieni, szkolenia nie były organizowane $(14,0 \%)$ lub o tym nie wiedzieli $(6,5 \%)$. Ponad połowa osób objętych badaniem $(52,3 \%)$ podała, że na 
Of all the respondents, $79.4 \%$ confirmed that trainings in injury prophylaxis are conducted in their workplace. The remaining subjects stated that such trainings were not organized in their workplace $(14.0 \%)$ or they did not know about it (6.5\%). Over half of the subjects (52.3\%) said that the trainings in their workplaces were organized at least once a year, while $14.0 \%$ of the respondents claimed that such trainings take place every other year, and $13.1 \%$ of them said that they occurred twice a year. Those polled declared that they attend trainings concerning injury prevention in their workplaces in great numbers $(75.7 \%)$, of which $34.6 \%$ participate in every training, $28.0 \%$ do it often, and $13.1 \%$ do it relatively rarely. On the other hand, $24.3 \%$ of nurses revealed that they had never taken part in such a training. Last year, $54.2 \%$ of the subjects attended only one training in injury prevention at work. Participation in two such trainings was confirmed by $4.7 \%$ of the studied people, while $41.1 \%$ reported that they did not take part in such trainings in the indicated time period. Participation in trainings did not have a statistically significant influence on the incidence of injuries in the group of people studied (Mann-Whitney U test, $\mathrm{p}=0.296262$ ).

\section{DISCUSSION}

The actual extent of injury occurrence among the medical personnel in our country is not fully known. This is due to, among others, lack of surveillance of these events through the introduction of a central register of occupational exposures imitating EPINet (The Exposure Prevention Information Network) which is currently operating in the USA and similar ones functioning in Canada, Spain, Italy, Great Britain and Japan (8). Due to the lack of a national register, the exact number of people who suffer from injuries is not known. There is also no data on the occupational groups subject to exposure and the circumstances in which these incidents take place. The national medical literature still lacks general studies on the epidemiology of occupational exposure of medical workers to injury, and the few attempts at collecting data from the whole country are a reflection of the situation from a decade ago (10). The majority of the information available is individual data on particular occupational groups, people working in a particular healthcare institution or only one region of a country $(9,11)$. On the local scale, no registers of exposures are kept for individual healthcare institutions which would enable a reliable analysis of the situation. Only some medical institutions carry out selective analyses of the incidence of occupational exposures among medical professionals (9-11).

Exposure of a medical worker to injury can be expressed as various rates. In 2012, in France, the number of injuries amounted to $6.3 \%$ per 100 beds terenie ich zakładów pracy szkolenia organizowane są przynajmniej raz w roku, z kolei $14,0 \%$ respondentów oświadczyło, że takie szkolenia odbywają się co dwa lata, a $13,1 \%$, że dwa razy w roku. Ankietowani deklarowali, iż licznie uczestniczą w szkoleniach z zakresu profilaktyki przeciw zranieniom na terenie zakładu pracy $(75,7 \%)$, z czego $34,6 \%$ bierze udział w szkoleniach zawsze, $28,0 \%$ często, a $13,1 \%$ stosunkowo rzadko. Natomiast $24,3 \%$ pielęgniarek zaznaczyło, że nigdy nie brało udziału w takim szkoleniu. W ostatnim roku 54,2\% badanych uczestniczyło tylko w jednym szkoleniu z zakresu przeciwdziałania zranieniom w pracy zawodowej. Obecność na dwóch takich szkoleniach potwierdziło $4,7 \%$ badanych, natomiast $41,1 \%$ podało, że nie brało udziału w takim szkoleniu we wskazanym okresie. Uczestnictwo w szkoleniach nie miało statystycznie istotnego wpływu na wystąpienie zranień w grupie ankietowanych (Test Manna-Whitneya, $p=0,296262$ ).

\section{DYSKUSJA}

Rzeczywiste rozmiary występowania zranień wśród personelu medycznego w naszym kraju nie są dobrze znane. Wpływa na to między innymi brak monitorowania zdarzeń przez wprowadzenie centralnego rejestru ekspozycji zawodowych na wzór Sieci Informacyjnej Prewencji Zdarzeń Ekspozycyjnych (EPINet ang. The Exposure Prevention Information Network) działającej obecnie w USA i podobnych funkcjonujących w Kanadzie, Hiszpanii, Włoszech, Wielkiej Brytanii i Japonii (8). Ze względu na brak krajowego rejestru nie jest znana dokładna liczba osób, które ulegają zranieniom. Brakuje również danych o grupach zawodowych ulegających ekspozycji oraz o okolicznościach, w jakich występują takie zdarzenia. W krajowej literaturze medycznej nadal brakuje ogólnych opracowań z zakresu epidemiologii zawodowego narażenia pracowników medycznych na zranienia, a nieliczne próby zebrania danych $\mathrm{z}$ całego kraju przedstawiają sytuację sprzed dekady (10). Większość dostępnych informacji to dane jednostkowe odnoszące się do konkretnej grupy zawodowej, osób pracujących w danej placówce ochrony zdrowia lub jednego regionu kraju $(9,11)$. W skali lokalnej brakuje prowadzonych rejestrów ekspozycji dla poszczególnych jednostek leczniczych, które umożliwiałyby rzetelną analizę sytuacji. Tylko niektóre instytucje lecznicze przeprowadzają wybiórczo analizę występowania incydentów ekspozycji zawodowych wśród pracowników medycznych (9-11).

Narażenie pracownika medycznego na zranienie wyrażane jest różnymi współczynnikami. W 2012 r. we Francji liczba zranień wynosiła 6,3\% na 100 łóżek (12). W Stanach Zjednoczonych w 2015 r. współczyn- 
(12). In the United States, in 2015, the injury incident rate amounted to 31.7 per day (13). It is difficult to estimate the actual number of exposure events in Poland due to, among others, the diverse methods for preparing reports on occupational exposure. The frequency of exposure incidents associated with injury registered among the healthcare workers in 2003 reached the level of $0.31 \%(10)$. However, there could have been many more such cases considering their low reporting rate in our country (10). It is assumed that the proportion of incidents of exposure is higher than the one reported $(9,10,14)$.

In the study carried out by Braczkowska B. et al. in 1998-2006 in the Silesian province in Poland, it was found that nurses suffered from injuries most often $(65 \%)$ and the frequency of those incidents was $0.35 \%(14)$. The incidence of exposure events among the nurses participating in our study was significantly higher, as it was declared by over $60 \%$ of the subjects. Injuries were more frequent in the case of in-patient healthcare institutions, and in them, the workers most prone to injuries were employed in surgical units, in which sharps are used. In a study carried out by Szczypta A. et al. in one of the hospitals of Kraków, a total of around $72 \%$ of all events took place in surgical units (9). Similar results were obtained in our study. However, a study by Garus-Pakowska A. and Szatko $F$. does not confirm a significantly higher risk of injury in surgical units in comparison with medical assessment units (5).

On the basis of the results of analysis of the answers provided by the subjects in this study, it was concluded that workers with a longer work experience were more prone to exposure. It is confirmed by the results obtained by Garus-Pakowska A. and Szatko F. (5). While Bilski B. et al., based on their results, found that professional experience has significant influence on the incidence of injuries among nurses since the people with little experience or the ones who, in the course of their work, have less contact with medical sharps are more susceptible to injuries (15).

The work of a nurse also requires the application of various types of medical equipment. This equipment is often sharp and calls for precision and caution when in use. In this study, the respondents declared various circumstances which led to their injuries. The results of our research are substantiated by studies carried out by, among others, Bilski B. et al, who found that injuries most often occur when the needle is being taken off the syringe or when it is being placed into overfilled hard-shell containers (6). In a study by Rogowska-Szadkowska D. et al., 64\% of the subjects admitted that they sometimes put the protective cap back on the previously used injection needle, despite knowing the procedures in force (16). Also the studies nik incydentów zranień wynosił 31,7 na dzień (13). W Polsce trudno ocenić rzeczywistą liczbę zdarzeń ekspozycyjnych między innymi ze względu na zróżnicowany sposób sporządzania raportów dotyczących ekspozycji zawodowych. Częstość rejestrowanych ekspozycji związanych ze zranieniem wśród pracowników ochrony zdrowia w 2003 r. osiągnęła poziom 0,31\% (10). Jednak przypadków tych mogło być zdecydowanie więcej, ze względu na ich niską zgłaszalność w naszym kraju (10). Domniemywa się, iż odsetek incydentów ekspozycji jest wyższy od zgłaszanych $(9,10,14)$.

W badaniach przeprowadzonych przez B. Braczkowska i wsp. w latach 1998-2006 w województwie śląskim stwierdzono, że najczęściej zranieniom ulegają pielęgniarki (65\%), a częstość tych incydentów kształtowała się na poziomie $0,35 \%$ (14). Wśród pielęgniarek/pielęgniarzy uczestniczących $\mathrm{w}$ badaniu własnym częstość zdarzeń ekspozycyjnych była znacznie większa, gdyż deklarowało ją ponad $60 \%$ ankietowanych. Częściej zranieniom ulegali pracownicy placówek zamkniętych, a wśród nich pracujący na oddziałach zabiegowych, na których stosowany jest ostry sprzęt. W badaniu przeprowadzonym przez A. Szczypte i wsp. w jednym z krakowskich szpitali łącznie około $72 \%$ wszystkich zdarzeń miało miejsce na oddziałach o charakterze zabiegowym (9). Podobne wyniki uzyskano w badaniu własnym. Natomiast w badaniu A. Garus-Pakowskiej i F. Szatko nie potwierdzono istotnie większego ryzyka zranień na oddziałach zabiegowych w porównaniu z oddziałami zachowawczymi (5).

Na podstawie wyników analizy odpowiedzi udzielonych przez ankietowanych w niniejszym badaniu stwierdzono, że wraz z długością stażu pracy wzrastała liczba ekspozycji. Potwierdzają to wyniki uzyskane przez A. Garus-Pakowska i F. Szatko (5). Z kolei B. Bilski i wsp. na podstawie uzyskanych wyników stwierdzili, że doświadczenie zawodowe ma istotny wpływ na występowanie zranień wśród pielęgniarek, gdyż osoby z małym doświadczeniem lub te, które w trakcie swojej pracy mają mniejszy kontakt z ostrym sprzętem medycznym są bardziej narażone na zranienia (15).

Praca pielęgniarki wymaga również używania wszelkiego rodzaju sprzętu medycznego. Często sprzęt ten jest ostry i wymaga precyzji oraz ostrożności podczas posługiwania się nim. W niniejszym badaniu respondenci deklarowali różne okoliczności, w których doszło do zranienia. Wyniki naszego badania znajdują potwierdzenie $\mathrm{w}$ badaniach przeprowadzonych między innymi przez $B$. Bilskiego, który wykazał, że do zranień dochodzi najczęściej podczas zdejmowania igły ze strzykawki lub umieszczania jej w przepełnionych pojemnikach twardościennych (6). W badaniu $D$. 
conducted by Smoliński P. et al., Kowalska J. D. et al. and Braczkowska B. et al. demonstrated that, in the majority of the cases, needlestick injuries caused harm and amounted to $73-89 \%(11,14,17)$. It is assumed that around $80 \%$ of the entire occupational exposure among nurses, physicians and other medical workers is associated with the use of needles and other sharps (18).

In the scientific literature, there is a concept of sense of urgency, which is defined as a sense of pressure to perform the delegated tasks promptly due to heavy workload and/or nursing staff shortages $(19,20)$. In our study, the respondents admitted that the occurrence of injuries was affected by psychosocial factors, among others, haste. Also, in a survey study conducted by Piatek A., causes of injuries cited by the respondents were, among others, haste and tiredness, too few workers and too many patients per nurse, as well as inappropriate relationships between the members of the therapeutic team, improper organization of work and irregularities as regards the equipment of workstations (21). Likewise, Mehrdad R. et al. concluded that there is a significant relationship between the existence of psychosocial factors at work (including stress) and the exposure to injuries among the nursing staff (22). Smith $D$. R. et al., in a study which encompassed 995 nurses from Japan, observed that working in a hurry resulted in occasional non-compliance with safetyensuring procedures which, in turn, makes the subjects much more vulnerable to punctures (odds ratio $[\mathrm{OR}]=$ 0.71, confidence interval 95\% [CI $]=0.47-1.06)(23)$.

It is also relevant that many incidents of injuries among nurses are not reported. When analyzing the results of our study, it was found that over $27 \%$ of the respondents have never notified their supervisors about injuries that occurred in the course of work. In a study conducted by Rybacki $M$. et al. on a group of 1138 workers in 2009-2010, it was demonstrated that $39.7 \%$ of the subjects did not report the incident of occupational exposure associated with a breach in the continuity of skin tissue resulting from injury (24). Similarly, in a study performed by Gańczak $M$. et al., $82.5 \%$ of the studied people failed to report a medical sharps injury (25). Also, Smoliński P. et al. confirmed a large percentage of people (as many as $80 \%$ ) who do not report injuries (11).

The main reason for failure to report an incident of injury by the nurses studied was lack of time (38.9\%). Other motivations indicated were lack of knowledge about the necessity of reporting the situation to appropriate services (33.3\%), fear of having to undergo testing and then see the results $(16.7 \%)$ and too many formalities during the entire procedure (11.1\%). For comparison, in a study conducted by Gańczak $M$. et al., $82.5 \%$ of the subjects did not report cuts with
Rogowskiej-Szadkowskiej i wsp. 64\% badanych przyznało, że czasem zakłada ponownie nakładkę ochronną na użytą wcześniej igłę do iniekcji, pomimo znajomości obowiązujących procedur (16). Również badania przeprowadzone przez P. Smolińskiego i wsp., J. D. Kowalska i wsp. oraz B. Braczkowska i wsp. wykazały, że w większości przypadków zranienia powodowały zakłucia igłami i wynosiły $73-89 \%(11,14,17)$. Uznaje się, iż około 80\% wszystkich ekspozycji zawodowych wśród pielęgniarek, lekarzy i innych pracowników medycznych związane jest $\mathrm{z}$ używaniem igieł oraz innych ostrych narzędzi medycznych (18).

W literaturze tematu funkcjonuje pojęcie ,sense of urgency", które jest definiowane jako poczucie presji, aby zlecone zadania wykonywać szybko z powodu dużego obciążenia pracą i/lub niedoboru personelu pielęgniarskiego $(19,20)$. W naszym badaniu respondenci przyznali, że na wystąpienie zranień wpływ miały czynniki psychospołeczne m.in. pośpiech. Również w badaniu sondażowym przeprowadzonym przez A. Piątek za przyczynę zranień ankietowani uznali między innymi pośpiech i zmęczenie, zbyt mało personelu oraz zbyt wielu pacjentów przypadających na jedną pielęgniarkę, ponadto nieprawidłowe relacje członków zespołu terapeutycznego, niewłaściwą organizację pracy oraz nieprawidłowości w wyposażeniu stanowisk pracy (21). (Również R. Mehrdad i wsp. stwierdzili, że istnieje znaczący związek między obecnością czynników psychospołecznych w pracy (w tym stresu) a narażeniem na zranienia wśród personelu pielęgniarskiego (22). D. R. Smith i wsp. w badaniu, które objeło 995 pielęgniarek z Japonii zauważyli, że praca w pośpiechu powodowała, iż nie zawsze stosowały się do procedur zapewniających bezpieczeństwo i dlatego były znacznie bardziej narażone na zakłucia (iloraz szans [OR] $=0,71$, przedział ufności 95\% [CI $]=0,47-1,06)(23)$.

Istotny jest również fakt, że wiele incydentów zranień wśród pielęgniarek nie zostało zgłoszonych. Analizując wyniki naszego badania stwierdzono, że ponad $27 \%$ ankietowanych nigdy nie zgłosiło przełożonym zranienia $\mathrm{w}$ trakcie pracy. W badaniu przeprowadzonym przez M. Rybackiego w latach 2009-2010 na grupie 1138 pracowników wykazano, iż 39,7\% badanych nie zgłosiło incydentu ekspozycji zawodowej związanej z naruszeniem ciągłości tkanki skórnej powstałej w wyniku zranienia (24). Podobnie w badaniu przeprowadzonym przez $M$. Gańczak i wsp. $82,5 \%$ badanych nie zgłosiło zranienia ostrym sprzętem medycznym (25). Także P. Smoliński i wsp. potwierdził duży odsetek osób (aż 80\%), które nie zgłaszają zranień (11).

Najczęstszą przyczyną niezgłaszania incydentu zranienia wśród badanych pielęgniarek był brak czasu $(38,9 \%)$. Jako przyczynę wskazano również brak wiedzy o konieczności zgłaszania zaistniałej sytuacji odpowiednim służbom (33,3\%), obawę przed mającymi nastąpić badaniami i wynikami badań $(16,7 \%)$ oraz zbyt dużą ilo- 
medical equipment to appropriate services involved in the initiation of the post-exposure procedure (25). The reason for not reporting occupational exposures was the belief that the patient was non-infectious $(59.6 \%)$ as well as lack of time $(36.5 \%)$. The results of the research presented by Braczkowska B. et al. demonstrated that around $78 \%$ of the subjects do not report incidents of injury and underestimate the risk of infection (14).

An indispensable element in reducing the number of injuries is organizing trainings in (or outside of) the workplace. As it is clear from our research, the vast majority of nurses $(75.7 \%)$ participate in trainings concerning injury prevention. Rybacki $M$. and Piekarska A. believe that more emphasis should be placed on employee training in occupational exposure and its prevention (26). As is pointed out by Gańczak $M$., trainings have a great influence on the safety of performing professional duties, and therefore, the decrease in the number of incidents associated with exposure. Similar conclusions were reached by GreenMcKenzie J. et al. following a survey among healthcare workers, including nurses, in the USA (27). The metaanalysis assessing the strategies for injury prevention while providing medical services concluded that the organization of trainings decreases the risk of injury occurrence by as much as $34 \%$ (28). However, as it is clear from the study conducted by Gańczak M., 25\% of nurses and over $50 \%$ of physicians in surgical units have never participated in trainings in the course of their professional career (18). We obtained similar results in our study, as $24.3 \%$ of nurses have never taken part in a training.

The results of studies obtained certainly do not exhaust the topic associated with the occurrence of injuries among nurses who are particularly susceptible to perils in the course of performing their professional duties. However, they do point to a need to create a national surveillance tool that would monitor occupational exposure among medical workers.

\section{CONCLUSIONS}

1. Nurses are still subject to injuries in the course of their professional work.

2. Not every injury is reported by the person exposed.

3. Work experience determines the incidence of injuries among nurses. The greater the work experience, the more frequent the injuries in the professional work.

4. The instrument that causes injuries most often is the needle.

5. Fatigue and haste at work are the main factors of the professional exposure of nurses. ścią formalności podczas trwania całej procedury $(11,1 \%)$. Dla porównania w badaniach przeprowadzonych przez M. Gańczak i wsp. $82,5 \%$ badanych nie zgłosiło faktu skaleczenia sprzętem medycznym odpowiednim służbom zajmującym się wszczęciem procedury poekspozycyjnej (25). Za przyczynę braku zgłoszenia wystapienia ekspozycji zawodowej było przekonanie o niezakaźności pacjenta (59,6\%), a także brak czasu (36,5\%). Wyniki badania przedstawione przez B. Braczkowska i wsp. wykazały, że około $78 \%$ badanych nie zgłasza incydentów zranienia i bagatelizuje ryzyko wystąpienia zakażenia (14).

Nieodzownym elementem w zmniejszeniu liczby zranień jest organizowanie szkoleń w zakładach pracy lub też poza nimi. Jak wynika $\mathrm{z}$ naszego badania zdecydowana większość pielęgniarek $(75,7 \%)$ bierze udział w szkoleniach z zakresu profilaktyki zranień. M. Rybacki i A. Piekarska uważają, że na szkolenia pracowników w zakresie ekspozycji zawodowej i jej zapobieganiu powinien być położony większy nacisk (26). Jak wskazuje M. Gańczak szkolenia w znaczny sposób wpływają na bezpieczeństwo wykonywania obowiązków zawodowych, przez co zmniejsza się liczba incydentów związanych z ekspozycją. Do podobnych wniosków doszła J. Green-McKenzie z zespołem ankietując pracowników służby zdrowia, w tym pielęgniarki, w USA (27). W metaanalizie oceniającej strategie zapobiegania urazom w czasie świadczenia opieki medycznej stwierdzono, że organizowanie szkoleń zmniejsza ryzyko wystąpienia zranień nawet o 34\% (28). Jednak jak wynika z przeprowadzonego przez M. Gańczak badania $25 \%$ pielęgniarek i ponad $50 \%$ lekarzy oddziałów zabiegowych nie uczestniczyło nigdy w szkoleniach w trakcie trwania swojej pracy zawodowej (18). Podobne wyniki uzyskano w naszym badaniu, ponieważ $24,3 \%$ pielęgniarek nigdy nie wzięło udziału w szkoleniu.

Otrzymane wyniki badań niewątpliwie nie wyczerpują tematu związanego z występowaniem zranień wśród pielęgniarek, które w sposób szczególny narażone są na niebezpieczeństwo w trakcie wykonywania swoich obowiązków zawodowych. Wskazują jednak na potrzebę utworzenia ogólnopolskiego narzędzia monitorującego ekspozycję zawodową pracowników medycznych.

\section{WNIOSKI}

1. Pielęgniarki nadal ulegają zranieniom $\mathrm{w}$ trakcie pracy zawodowej.

2. Nie każde zranienie jest zgłaszane przez osobę eksponowaną.

3. Staż pracy determinuje częstość występowania zranień pielęgniarek. Im dłuższy staż pracy, tym częściej występują zranienia w pracy zawodowej.

4. Najczęstszym sprzętem powodującym zranienia jest igła.

5. Zmęczenie i pośpiech $\mathrm{w}$ pracy stanowią główne czynniki zranień. 


\section{REFERENCES}

1. Świątkowska B. Zagrożenia zawodowe pracowników opieki zdrowotnej: Co wiemy i co możemy zrobić? Probl Hig Epidemiol 2010;91(4):522-9.

2. Polskie Towarzystwo Lekarzy Epidemiologów. Zranienia Ostrymi Narzędziami. Warszawa; 2013

3. Prüss-Üstün A, Rapiti E, Hutin Y. Estimation of the global burden of disease attributable to contaminated sharps injuries among health-care workers. Am J Ind Med. 2005;48(6):482-90.

4. Jarosik M, Garus-Pakowska A. Wiedza i przestrzeganie procedur higienicznych jako element profilaktyki przeciwzakaźnej w pracy pielęgniarek. Hygeia Public Heal 2012;47(2):215-22.

5. Garus-Pakowska A, Szatko F. Ekspozycje przezskórne personelu medycznego. Med $\mathrm{Pr}$ 2011;62(5):473-80.

6. Bilski B, Kostiukow A, Ptak D. Incydenty stwarzające ryzyko zakażenia drogą krwiopochodną w pracy białego personelu służby zdrowia. Med $\mathrm{Pr}$ 2006;57(4):375-9.

7. Moayed MS, Mahmoudi H, Ebadi A, Sharif Nia H. Stress and Fear of Exposure to Sharps in Nurses. Iran J Psychiatry Behav Sci 2016;10(3):e3813.

8. The Exposure Prevention Information Network. https://www.medicalcenter.virginia.edu/epinet/ about_epinet.html

9. Szczypta A, Różańska A, Bulanda M. Analiza ekspozycji zawodowej pracowników medycznych w latach 1998-2013 na patogeny przenoszone drogą krwi na przykładzie szpitala o profilu zabiegowym. Med Pr 2015;65(6):723-32.

10. Serafińska S, Smoliński P, Gładysz A. Krytyczna ocena rejestracji ekspozycji zawodowych związanych z naruszeniem ciągłości tkanek oraz wynikających $\mathrm{z}$ tego konsekwencji - wśród pracowników polskiej służby zdrowia. Med Pr 2006;57(5):439-50.

11. Smoliński P, Serafińska S, Gładysz A. Ocena niedoszacowania częstości ekspozycji na materiał biologiczny wśród pracowników polskiej służby zdrowia - analiza prospektywna. Med Pr 2006;57(6):507-16.

12. Floret N, Ali-Brandmeyer O, L'Hériteau F, Bervas C, Barquins-Guichard S, Pelissier G, et al. Sharp Decrease of Reported Occupational Blood and Body Fluid Exposures in French Hospitals, 20032012: Results of the French National Network Survey, AES-RAISIN. Infect Control Hosp Epidemiol 2015;36(8):963-8.

13. EPINet Research Group. EPINet Report for Needlestick and Sharp Object Injuries https://internationalsafetycenter.org/wp-content/uploads/2017/06/ Official-2015-NeedleSummary.pdf
14. Braczkowska B, Kowalska M, Beniowski M, Zejda JE, Mazur W, Witor A. Zawodowa ekspozycja pracowników służb medycznych na wirus HIV w województwie śląskim. Med Pr 2010;61(3):315-22.

15. Bilski B, Kostiukow A, Ptak D. Incydenty stwarzające ryzyko zakażenia drogą krwiopochodną w pracy białego personelu służby zdrowia. Med $\mathrm{Pr}$ 2006;57(4):375-9.

16. Rogowska-Szadkowska D, Stanisławowicz M, Chlabicz S. Ryzyko ekspozycji pracowników opieki medycznej na drobnoustroje przenoszone przez krew zwiększają utrzymujące się złe przyzwyczajenia. Przegl Epidemiol 2010;64(2):293-5.

17. Kowalska JD, Firląg-Burkacka E, Niezabitowska M, Bąkowska E, Ignatowska A, Pulik P, et al. Proflaktyka poekspozycyjna zakażenia HIV prowadzona w Poradni Profilaktyczno-Leczniczej Wojewódzkiego Szpitala Zakaźnego w Warszawie w latach 2001-2002. Przegl Epidemiol 2006;60(4):789-94.

18. Gańczak M. Ekspozycja zawodowa - Ocena skali problemu i metod prewencji. Mag Pielęgniarek i Położnych 2012;7-8:36-7.

19. Patrician PA, Pryor E, Fridman M, Loan L. Needlestick injuries among nursing staff: Association with shift-level staffing. Am J Infect Control 2011;39(6):477-82.

20. Clarke SP, Rockett JL, Sloane DM, Aiken LH. Organizational climate, staffing, and safety equipment as predictors of needlestick injuries and near-misses in hospital nurses. Am J Infect Control 2002;30(4):207-16.

21. Piątek A. Błędy i wykroczenia w praktyce zawodowej pielęgniarek i położnych a bezpieczeństwo pacjentów. Zdrowie Publiczne 2005, 115(4):465-470.

22. Mehrdad R, Atkins EH, Sharifian SA, Pouryaghoub G. Psychosocial factors at work and blood-borne exposure among nurses. Int J Occup Environ Med 2014 Jan;5(1):32-9.

23. Smith DR, Mihashi M, Adachi Y, Shouyama Y, Mouri F, Ishibashi N, et al. Organizational climate and its relationship with needlestick and sharps injuries among Japanese nurses. Am J Infect Control 2009;37(7):545-50.

24. Rybacki M, Piekarska A, Wiszniewska M, Walusiak-Skorupa J. Work safety among Polish health care workers in respect of exposure to bloodborne pathogens. Med Pr 2013;64(1):1-10.

25. Gańczak M, Szych Z, Karakiewicz B. Ocena zawodowego narażenia na zakażenie $\mathrm{HBV}, \mathrm{HCV}$ i HIV u personelu oddziałów ginekologii i położnictwa. Med Pr 2012;63(1):11-7.

26. Rybacki M, Piekarska A. Zapobieganie zakażeniom krwiopochodnym u personelu medycznego : 
poradnik dla służb BHP, PIS i PIP, pracodawców i pracowników, Łódź: Oficyna Wydawnicza Instytutu Medycyny Pracy im. prof. J. Nofera; 2012

27. Green-McKenzie J, McCarthy RB, Shofer FS. Characterisation of occupational blood and body fluid exposures beyond the Needlestick Safety and Prevention Act. J Infect Prev 2016;17(5):226-32.

28. Tarigan LH, Cifuentes M, Quinn M, Kriebel D. Prevention of Needle-Stick Injuries in Healthcare Facilities: A Meta-Analysis. Infect Control Hosp Epidemiol 2015;36(7).
Received: 22.02.2018

Accepted for publication: 18.07.2018

Otrzymano: 22.02.2018 r.

Zaakceptowano do publikacji: 18.07.2018 r.

Address for correspondence:

Adres do korespondencji:

Katarzyna Talaga-Ćwiertnia

Institute of Mycology, Department of Microbiology

Faculty of Medicine, Jagiellonian University Medical College ul. Czysta 18, 31-121 Kraków

Tel. 12/ 6332567 ext. 231

E-mail: katarzyna.talaga@uj.edu.pl 